\title{
「ゲフィチニブ」に関する声明
}

\author{
第 44 回日本肺癌学会会長 加藤 治文 \\ ゲフィチニブの適正使用検討委員会 \\ 委員長 西條 長宏 \\ 委 員 工藤 翔二, 福岡 正博, 根来 俊一, \\ 坪井 正博, 多田 弘人, 浅村 尚生, \\ 早川 和重
}

ゲフィチニブ (イレッサ®) は，EGFR チロシンキナーゼ阻害作用により抗腫瘍活性を発揮するとされ ている抗悪性腫瘍剤である. 我が国も参加した第 II 相国際共同治験 (文献 1) で，プラチナ製剤を含む前 化学療法無効ないし再発進行非小細胞肺癌に対して, 日本人では $27.5 \%$ の奏効率が認められ, 2002 年 7 月 5 日に世界に先駆けて手術不能又は再発非小細胞肺癌を適応症として厚生労働省から承認された？ の後, 2003 年 5 月 5 日に米国食品医薬品局（FDA）は, 標準的化学療法に不応となった進行非小細胞肺 癌に対しゲフィチニブを単独投与で使用することを承認した。 また, 2003 年 5 月 1 日にはオーストラリ アでもゲフィチニブが承認された.

しかし,我が国では市販後本剤投与が原因と思われる重篤な間質性肺炎/急性肺障害が次々と報告され 社会的問題となっている. 厚生労働省の集計によれば 2003 年 4 月 22 日現在, 間質性肺炎/急性肺障害が 616 例にみられ, うち 246 例が死亡した.アストラゼネカ社が厚生労働省に報告したゲフィチニブ服用患 者数は 2003 年 4 月 25 日現在推定約 28300 人とされている.

これに対して, 2002 年 10 月 15 日に厚生労働省の指示により, 本剂による間質性肺炎/急性肺障害につ いての「緊急安全性情報」が発出され，同時に本剤の添付文書の改訂が行われたささらに，2002 年 12 月 25 日の厚生労働省医薬局安全対策課が行った「ゲフィチニブ安全性問題検討会」における検討結果か ら,「今後の対応」として，5項目の対策を実施する必要があるとされた。すなわち，「1 インフォーム ド・コンセントや情報提供の徹底」, 「2 より適切な管理の下での使用の徹底」, 「3 間質性肺炎, 肺線 維症, またはこれらの疾患の既往歴のある患者への使用を慎重投与に設定」,「4 『服用者向け情報提供 資料』の作成」,「5 企業による市販後安全性対策の強化」がそれである.また， 2003 年 5 月 2 日にも同 検討会が開催され，その結果本剤の添付文書が改訂された（2003 年 4 月改訂，第 6 版).

一方，アストラゼネカ社は「ゲフィチニブの急性肺障害・間質性肺炎に関する専門家会議」を組織し， 2002 年 12 月 13 日までに主治医から自発報告された本剤との関連が疑われる急性肺障害・間質性肺炎 (Interstitial lung disease, 以下 ILD と略す) 発症例 358 例中詳細情報が入手できた 152 例を対象に解析 し， 2003 年 3 月 26 日付で解析結果を報告した (文献 2). それによれば，1）日本における ILD の発症率 は約 $1.9 \%$ （死亡率 $0.9 \%$ ）で海外の約 6 倍であること, 2) ILDの予後不良因子として, 男性, 扁平上皮 癌, 特発性肺線維症等を有するもの, Performance Status 2 以上, 喫煙歴のあるもの, ゲムシタビン治療 歴のないものがあげられ, なかでも多変量解析で特発性肺線維症等を有するもの, 男性, 扁平上皮癌が 「主要な予後因子となる可能性が示唆された」こと，3）ILD 発症例の症状としては, 息切れ $75 \%$, 発熱 $42.1 \%$ ，ラ音 $32.9 \%$, 乾性咳嗽 $27.0 \%$,4）画像情報のある 134 例中約 $20 \%$ が感染等の他疾患と判断され たこと，5）ILDの CT 所見は従来報告された薬剤性肺障害のそれと特段の相違はないこと，6)剖検例の 
基本的病理組織像は，びまん性肺胞障害であったことなどが明らかになった．この検討および西日本胸 部腫瘍臨床研究機構などの研究成果に基づき, 特発性肺線維症等の既存が本剤投与における ILD 発症の 危険因子であり，死亡につながる重要な危険因子あることなどが示された。

しかし，これら厚生労働省の対策も，アストラゼネカ社の報告も，行政と企業側からのもので, 肺癌 治療に携わる第一線の臨床医には隔靴掻痒の感は否めない，そこで，日本肺癌学会はゲフィチニブの適 正使用に関する見解をまとめることを目的として「ゲフィチニブの適正使用検討委員会」を設け，臨床 試験及び実地医療でのゲフィチニブ使用に関するガイドラインを作成した.

\section{1. 実地医療でのゲフィチニブ使用に関するガイドライン}

\section{○適応}

1）本剤添付文書の「効能・効果」に記載されている適応症である「手術不能又は再発非小細胞肺癌」 を厳守すること．「化学療法未治療例における有效性及び安全性は確立していない」,「術後補助療 法における有效性及び安全性は確立していない」ため，このような例では実地医療としては使用し ないこと.

2）本剂と他の抗悪性腫瘍剂や放射線治療との同時併用に抢ける有効性と安全性は証明されていない ので, 実地医療としては本郕を単剂で投与すること.

3）ゲフィチニブの治験における症例の適格条件や除外条件のうち, その主要な条件を原則として満た していること．その条件は，本邦も参加した本剤の国際共同第 II 相試験（文献 1）の症例選択・除 外基準(付 1)を参考とすること. それ以外の症例への投与は，未知の領域への試験的投与であり， 現時点では臨床試験以外では原則的に投与すべきではない。

4）本剂投与により利益（症状改善，腫瘍縮小効果）が得られる可能性の高い患者背景は, 腺癌，女性 であることが報告されているので, 症例選択の際に考慮すべきである.

5）本剤のリスクファクターとされている間質性肺炎 (特発性肺線維症, 放射線肺炎, 薬剂性肺炎など) 合併症例, 塵肺, 男性, 扁平上皮癌, 喫煙歴を有する者などに対する本剤投与は, 当該患者が本剤 から得られる利益が本剤投与による危険性を上回ると判断される場合に限定すること.

6) 本剤は, 肺癌化学療法に十分な経験をもつ医師が使用するとともに, 投与に際しては緊急時に十分 に措置できる医療機関で行うこと.なお, 間質性肺炎の専門医の助言を適宜得られる環境下での使 用が望ましい。

7）患者に本剂投与の目的, 投与法, 予想される効果と副作用（重篤な間質性肺炎/急性肺障害の発生 と死亡例がみられていること含む), 代替治療法の有無と有りの場合における当該治療法の利害得 失などを十分に説明した後に, 患者の自由意志による同意を文書で得ておくこと.

8）以上の条件を全て満たした場合に，本郕の投与を行うべきである.

\section{投与中の注意点}

1）急性肺障害 - 間質性肺炎の症状は, 発熱, 乾性咳嗽, 息切れ, 呼吸困難等であり, これら症状の全 てに注意すること．間質性肺炎の診断には注意媣い聴診が重要である.

2) 患者に予め上記自覚症状の意味を説明し，もしそれらを自覚した場合は，直ちに担当医師 (医療機 関）を受診するよう指導しておくこと.

3）医療機関側は，上記自覚症状を訴えた患者が常時受診可能な体制を整備しておくこと.

4）本剤投与開始 1 2 週間以内の急性肺障害・間質性肺炎の併発は死亡率が高いことが知られている （文献 3）ので，少なくとも投与開始後 2 週間の入院による厳重な観察が望ましい. 
5）上記自覚症状を一つでも認めた場合, 直ちに胸部単純 $\mathrm{X}$ 線写真撮影, 胸部 $\mathrm{CT}$ (可及的に $\mathrm{HRCT}$ ), 動脈血ガス分析 (特に $\mathrm{AaD}_{\mathrm{O}_{2}}$ 開大に注意), $\mathrm{DL}_{\mathrm{CO}}$ 等を行い, 急性肺障害・間質性肺炎発症の有無を 鑑別すること. 鑑別には投与前との比較が重要であり, 投与前にもこれら検査を行っておくことが 望ましい。

6）本剤投与開始後 7 8 週間以内に急性肺障害・間質性肺炎を発症する症例が多いため, 外来通院の 場合, 上記期間中は少なくとも週 1 回は診察を行い, 自他覚症状のチェック, 酸素飽和度, 胸部単 純 $\mathrm{X}$ 線写真撮影等の検査を行うことが望ましい。

7）本剤の治療効果は投与開始後早期に出現することが多いので, 開始後 1 カ月以上経過しても, 肺癌 に伴う自覚症状の改善がみられないか, 画像上の腫瘍縮小効果が全く認められない場合は, 投与中 止を考慮すること.

\section{急性肺障害・間質性肺炎出現時の対応}

1）急性肺障害・間質性肺炎出現時は，直ちに本剤の投与を中止する.

2）ステロイドホルモンの投与が，一部の急性肺障害・間質性肺炎に効果があるとの報告が散見され る. ステロイドホルモンの投与が禁忌でなければ，メチルプレドニゾロン $500 〜 1000 \mathrm{mg}$ を 3 日間 投与するパルス療法を考慮すること．なお，ステロイド剤の継続投与で効果がみられた症例では， その漸減は慎重に行うこと.

3）免疫抑制剂の効果は, ステロイドホルモン以上に不明確である.

\section{2. 臨床試験におけるゲフィチニブ使用に関するガイドライン}

\section{適応}

1）臨床試験は理論的には全ての非小細胞肺癌症例が対象となり得る。しかし, 我が国の医師主導の臨 床試験は現実的には保険医療の範囲内で行わざるを得ない.したがって, 治験を除く医師主導の臨 床試験においては, 対象疾患は本片添付文書の「効能・効果」に記載されている適応症である「手 術不能又は再発非小細胞肺癌」の範囲内で行わざるを得ない. 実施に当たっては, ヘルシンキ宣言 を遵守すること. 当該プロトコールが医学的に妥当であること. 以下の項目は全てこれらの条件を 満たしていること.

2）化学療法未治療例の臨床試験は可能.

3）治験以外の「術後補助療法」の臨床試験は不可.

4）他の抗覀性腫瘍剤や放射線治療との同時併用に関する臨床試験は可能.

5）臨床試験においても，間質性肺炎（特発性肺線維症，放射線肺炎，薬剤性肺炎など）合併症例，塵 肺合併例は除外すること。

6）本剤は, 肺癌化学療法に十分な経験をもつ医師が使用するとともに, 投与に際しては緊急時に十分 に措置できる医療機関で行うことを厳守すること.なお, 間質性肺炎の専門医の助言を適宜得られ る環境下での使用が望ましい。

7）文書によるインフォームド・コンセントの取得は必須.

\section{○投与中の注意点}

投与中に注意すべき点は, 実地医療の注意点と基本的に同様である.ただし, 患者の観察はより十分 に行われること. 観察項目, 観察時期, 投与中止規定等全てプロトコールに記載しておくこと. 


\section{○急性肺障害・間質性肺炎出現時の対応}

急性肺障害・間質性肺炎出現時の対応も，実地医療と同様である，対応法については，プロトコール に記載しておくこと.

付 1

「1 2レジメンの化学療法歴（少なくとも 1 レジメンは白金製剤を含む）を有する進行非小細 胞肺癌を対象としたZD1839 (IRESSA ${ }^{T M}$ ) $250 \mathrm{mg} /$ 日及び $500 \mathrm{mg} /$ 日の有効性を検討する無作為 化二重盲検並行群間第 II 相多施設共同臨床試験」における症例選択基準及び除外基準

\section{選択基準}

1. 局所進行（もしくは転移性）で手術または放射線療法で治癒可能でない III 期，または，IV 期の NSCLC 患者. 組織学的又は細胞学的に NSCLC と確認されている患者.

2. 1 2 2 ジメンによる化学療法（少なくとも 1 レジメンは白金製凨を含む）を受け再発もしくは抵 抗性を示した患者.

3. 病巣周辺が明膫な二方向測定可能病変が 1 つ以上ある患者. あるいは, 病巣周辺が明膫でないが, $\mathrm{X}$ 線で評価可能な病変が 1 つ以上ある患者.

4. WHO Performance Status（PS）が $0 \sim 2$ の患者.

5. 12 週以上の生存が予測される患者.

6. 18 歳以上の患者.

7. 治験に参加することについて文書で同意が得られている患者.

\section{除外基準}

1. 過去に 3 レジメン以上の化学療法を受けた患者.

2. 治療 1 日目の前 21 日以内に抗癌剂の全身投与の最終投与を受けた患者.

3. 以前に抗癌療法を受けてから CTC グレード 2 を超える慢性毒性が消失していない患者(脱毛症を 除く).

4. 治療 1 日目の前 14 日以内に放射線療法が施行された患者.

5. 以前の腫瘍手術又はその他の大手術からの回復が不十分である患者.

6. 上大静脈症候群を合併する患者.

7. 新たに脳内転移が診断された患者. なお，以前に脳内転移と診断され，治療された患者について は, 治療 1 日目の 2 カ月前以上，臨床的及び放射線学的に状態が安定している場合は，組み入れ 可とする.

8. 脊髄圧迫を伴う神経学的症状の徵候を有する患者.

9. 治験責任医師等の判断により, 重度又はコントロールされていない全身疾患があり, その結果 PS が 2 を超えている患者.

10．当該治験に参加することが望ましくないと考えられる著しい臨床症状又は臨床検査值の異常を有 する患者.

11. 好中球が $1500 / \mathrm{mm}^{3}$ 未満又は血小板が 7 万 5 千 $/ \mathrm{mm}^{3}$ 未満の患者.

12. 血清ビリルビンが基準值上限の 1.25 倍を超える患者.

13. 肝転移が認められない場合, ALT 又はAST が基準值上限の 2.5 倍を超える患者。あるいは, 肝転 移がある場合, 基準值上限の 5 倍を超える患者. 
14. 血清クレアチニンが基準值上限の 1.5 倍を超える患者.

15. ヒト免疫不全ウイルス $(\mathrm{HIV})$ 又は B 型肝炎を, 血液や他の体液から感染させる危険性があると治 験責任医師等が判断した患者.

16. 妊娠中又は授乳中の患者.

\section{文 献}

1. Fukuoka M, et al. Multi-institutional randomized phase II trial of Gefitinib for previously treated patients with advanced non-small-cell lung cancer. J. Clin. Oncol. 21: 2237-2246, 2003.

2. ゲフィチニブ（イレッサ® 錠 250）の急性肺障害・間質性肺炎（ILD）に関する専門家会議最終報告. アスト ラゼネカ. 2003.

3. ゲフィチニブによる急性肺障害・間質性肺炎の調査研究中間報告. NPO 西日本胸部腫瘍臨床研究機構. www. wjtog. org/. 2003. 